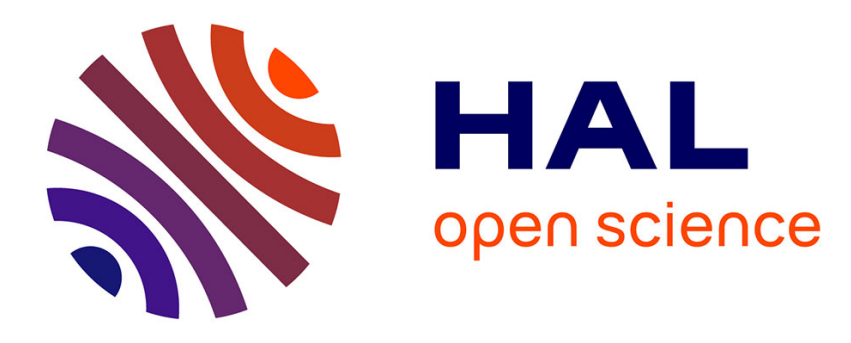

\title{
Tackling Undeclared Work in Europe: Lessons from a Study of Ukraine
}

\author{
Colin C. Williams
}

\section{To cite this version:}

Colin C. Williams. Tackling Undeclared Work in Europe: Lessons from a Study of Ukraine. European Journal of Industrial Relations, 2007, 13 (2), pp.219-236. 10.1177/0959680107078254 . hal-00570963

\section{HAL Id: hal-00570963 https://hal.science/hal-00570963}

Submitted on 1 Mar 2011

HAL is a multi-disciplinary open access archive for the deposit and dissemination of scientific research documents, whether they are published or not. The documents may come from teaching and research institutions in France or abroad, or from public or private research centers.
L'archive ouverte pluridisciplinaire HAL, est destinée au dépôt et à la diffusion de documents scientifiques de niveau recherche, publiés ou non, émanant des établissements d'enseignement et de recherche français ou étrangers, des laboratoires publics ou privés. 


\title{
Tackling Undeclared Work in Europe: Lessons from a Study of Ukraine
}

\begin{abstract}
This article reports a 2005-6 survey that displays the variety of undeclared work in Ukraine, involving not only an array of 'off-the-books' employees but also various types of informal self-employment as well as forms of undeclared work more akin to mutual aid. Governments pursuing a conventional deterrent approach towards undeclared work may thus eradicate precisely the entrepreneurship and active citizenship that they otherwise seek to nurture. A more nuanced approach to tackling this sphere is proposed. KEYWORDS: community participation - entrepreneurship - informal economy - public policy - tax compliance - Ukraine
\end{abstract}

\section{Introduction}

The issue of undeclared work has recently risen on the public policy agenda, not only in the EU where it is one of the top ten priorities for employment reform (European Commission, 2002, 2003a) but also in EastCentral European countries such as Ukraine, where the government has stated that tackling undeclared work is its top priority (Mission of Ukraine to European Communities, 2005; NRCU, 2005). The aim of this article is to evaluate the extent and nature of such work and how it can be tackled.

First, the various shifts in perceptions of undeclared work and public policy approaches will be outlined. Throughout Europe, mirroring an earlier trend in the Third World, there has been a move away from a wholly negative depiction of such work towards a more positive representation of this sphere as a seedbed of entrepreneurship and enterprise that needs to be harnessed (European Commission, 2003a, 2003b). Until now, however, few have empirically investigated the validity of this emergent view of undeclared work.

Second, I report a 2005/6 survey of undeclared work in Ukraine which indicates that this sphere indeed plays a major role in the development of enterprise and entrepreneurship. The great majority of the self-employed surveyed in Ukraine start up their business ventures by conducting at 
least a portion of their transactions on an undeclared basis. However, this positive role of undeclared work should not be exaggerated. On the one hand, over a quarter of undeclared work is conducted by off-the-books employees; on the other, a further half of all undeclared work is conducted for and by relatives, friends and neighbours under work relations more akin to mutual aid than employment. This entails a need for a more nuanced policy approach towards this sphere.

At the outset, it is necessary to define what is here meant by undeclared work or what has been variously called 'informal employment', the 'underground sector', 'shadow work' and the 'hidden economy'. The term refers to the paid production and sale of goods and services that are unregistered by, or hidden from the state for tax and/or benefit purposes but which are legal in all other respects (European Commission, 1998; Grabiner, 2000; ILO, 2002; Thomas, 1992; Williams and Windebank, 1998). It excludes both unpaid work and work (such as drug trafficking) in which the good and/or service provided is itself illegal; though non-declaration normally breaches tax or social security legislation. This economic sphere, like most others, possesses blurred edges. For example, some definitions include work performed in exchange for gifts, and services such as prostitution which are illegal in some nations but not others. Throughout this article, only work for monetary payment is included, and solely exchanges of goods and services legal in the country under consideration.

\section{Approaches Towards Tackling Undeclared Work}

Until recently, undeclared work in advanced capitalist societies has largely been viewed in negative terms as contributing little if anything to economic and social development (Gallin, 2001; Grabiner, 2000); the conventional public policy approach has thus been to eradicate such work (Hasseldine and Zhuhong, 1999; Sandford, 1999). Most European governments have sought to deter such working with increasingly punitive measures, increasing the penalties and coordinating strategy and action to improve detection rates. Such an approach has been supported by supranational agencies (European Commission, 1998; ILO, 2002) and many academic commentators (Castells and Portes, 1989).

In the UK, for example, the Chancellor of the Exchequer commissioned a report in 1999 which concluded that deterrence was the most appropriate way forward. For Grabiner (2000: 19):

as long as people can profit by not declaring their work, it will be impossible entirely to eradicate the informal economy. Therefore, the most effective way of tackling the problem is significantly to improve the likelihood of detecting and penalizing offenders. What is needed is a strong environment of deterrence. 
The outcome was a series of tougher penalties and improved detection methods. These included: increased sanctions for employers and employees, tighter controls, more severe punishments, increased cooperation and data exchange between authorities both on a national and international level, field checks, fraud hotlines and unannounced house visits to benefit claimants (Grabiner, 2000; Renooy et al., 2004; SBS, 2005).

In the Third World, however, it has been recognized for several decades that the undeclared sector acts as 'an incubator for business potential and ... transitional base for accessibility and graduation to the formal economy', and that many undeclared workers show 'real business acumen, creativity, dynamism and innovation' (ILO, 2002: 54). During the past few years, a similar view of undeclared work has started to emerge in Europe (Renooy et al., 2004; Small Business Council, 2004; Williams, 2004, 2006a).

For neoliberals, undeclared workers are heroes casting off the shackles of an over-burdensome state, and undeclared work is the 'essence of liberalism' (Sauvy, 1984). As De Soto (1989: 255) asserts, 'the real problem is not so much informality as formality'. Neoliberals view the recent growth of undeclared work as evidence of a resurgence of the free market against state regulation and union control; hence they argue for a laissezfaire approach towards such work combined with deregulation of the formal economy. With fewer regulations, the notion is that the distinction between formal and undeclared work will wither away so that the declared and undeclared spheres become inseparable; all activities would be performed in a manner now called 'undeclared', although such activity would be legitimate since it would not be breaking any rules.

In recent years in Europe, this representation of undeclared work as a site of entrepreneurship has also been taken up by a strand of socialdemocratic thought, also viewing undeclared enterprise as an asset, but only if this endeavour can be harnessed and moved into the formal economy (Renooy et al., 2004; Small Business Council, 2004; Williams, 2004, 2006a). If formalized, this would contribute to the development of an enterprise culture and the achievement of fuller employment. This emergent discourse finds a clear expression in the EU Employment Guideline 9 on undeclared work, first adopted in 2001. As the then Commissioner Anna Diamantopoulou put it:

Member states must increase efforts to quantify undeclared work, to cut it down and to transform it into regular employment. This is vital because of the direct link between combating undeclared work and hitting the Lisbon target of full employment by 2010 within a sound macroeconomic environment. (European Commission, 2002: 1, emphasis added)

To transfer such work into the formal economy, deterrents are seen as necessary but insufficient; they need to be combined with 'enabling' initiatives. As the 2003 version of the Guideline insisted, not only is there a 
need for push initiatives ('sticks') in the form of 'improved law enforcement and the application of sanctions' but also a range of pull initiatives ('carrots'), namely a 'simplification of the business environment' and the provision of 'appropriate incentives in the tax and benefits system' (European Commission, 2003b). In Ukraine similarly, although the emphasis is on deterrents, such as stricter sanctions, there is also a growing focus on a limited range of incentives including the simplification of reporting systems and the registration process as well as the provision of incentives for labour to leave the undeclared sphere (Novoseletsky, 2000).

Whether such 'enabling' policy initiatives actually differ from the neoliberal advocacy of deregulation is questionable. Though the call is for undeclared work to be brought into the legitimate realm rather than for the formal economy to be deregulated, the initiatives advocated seem to amount to little more than a 'low road' approach that seeks to strip away formal regulations and eliminate taxes. In this article, however, the intention is to explore a 'high road' approach to legitimizing undeclared work, in the context of an appreciation of the complex character of undeclared work. Below, and to move towards outlining such an approach, one of the first studies to unpack the diverse nature of undeclared work is reported.

\section{Undeclared Work in Ukraine}

Ukraine, the second largest successor state of the former Soviet Union, displays a wide gulf between the state and society and also severe economic problems as it attempts to make the transition to a market society. As the 2004 New Europe Barometer shows, there is a widespread perception that public officials are corrupt. While two-thirds of the population in new EU member states state that most officials are corrupt, 92 percent in Ukraine believe this is the case - the highest figure in all 13 East-Central European countries studied (Rose, 2005). Few Ukrainians believe in paying tax since they do not trust the state to use it for redistributive or collective purposes. Given that official employment declined by about onethird between 1990 and 1999 (Cherneyshev, 2006) and that 73 percent of Ukrainians assert that they receive insufficient from their main income to buy what they really need (Rose, 2005), it would be surprising if undeclared work were not rife.

Despite many previous surveys of the Ukraine labour market, no previous attempt has been made to collect data on undeclared work. Instead, there have only been indirect measurement methods using proxy indicators. According to these, such work in Ukraine is equivalent to 47-54 percent of GDP using physical input proxies (Schneider and Enste, 2000) and 55-70 percent using currency demand (Dzvinka, 2002), while government 
estimates, based on such proxies, assert that 55 percent of Ukraine's GDP is produced in the undeclared sphere (NCRU, 2005).

OECD experts in their handbook on measurement methods (OECD, 2002) and the most recent European Commission report on undeclared work (Renooy et al., 2004), as well as a host of academic evaluations (Thomas, 1992; Williams, 2004, 2006a; Williams and Windebank, 1998) have questioned the validity of such proxy measures and called for the use of direct surveys. Reflecting this, the European Commission is currently conducting a feasibility study for a Europe-wide direct survey of undeclared work (European Commission, 2005).

An initial attempt to collect data on undeclared work in Ukraine was therefore conducted, involving face-to-face structured interviews with 600 households. Given that previous studies in Europe reveal significant disparities in the level of undeclared work between affluent and deprived as well as urban and rural populations (Leonard, 1994; Renooy, 1990; Williams, 2005), maximum variation sampling was used to select four contrasting localities. Two were in Kiev, the capital: Perchersk, an affluent area, heavily populated by government officials and the new business class, and Vynogardar, a deprived neighbourhood comprising dilapidated Soviet-era housing with high unemployment and widespread poverty. Also chosen were a deprived rural area near Vasilikiv, which relied heavily on a nearby refrigerator manufacturing plant for employment until this closed nearly 10 years ago and since then has suffered high unemployment, and Užhgorod, a town on the Ukrainian/Slovakia border and the capital of the Carpathian region and where inhabitants complain that inflated prices caused by crossborder trade mean that they cannot afford many goods and services.

A spatially stratified sample of 150 households was selected in each locality. Thus if there were 3000 households in the area, the researcher called at every 20 th household. If there was no response or the interviewer was refused an interview, then the neighbouring household was visited. Table 1 provides a profile of the 600 respondents. Although this is a relatively small sample size and is not nationally representative, it nevertheless provides one of the first insights into the extent and nature of undeclared work in contemporary Ukraine.

Given that previous research on undeclared work elsewhere in Europe indicates that respondents find it difficult to recall instances of such work when unstructured interviews are used, and that the resultant data are often not comparable (Leonard, 1994; Williams, 2006a), a structured interview schedule was used. Besides gathering background data on gross household income, the employment status of household members, their employment histories, ages and gender, respondents were asked about the forms of work that they most rely on to maintain their living standard, the sources of labour that the household last used to complete 25 common domestic services, and whether they had undertaken any of these 
TABLE 1. Socio-economic Profile of Respondents to Ukraine Survey on Undeclared Work, 2005/06

\begin{tabular}{|c|c|c|c|c|c|}
\hline & Perchersk & Vynogradar & Vasilikiv & Užhgorod & Total \\
\hline No. of respondents & 150 & 150 & 150 & 150 & 600 \\
\hline \multicolumn{6}{|l|}{ Age } \\
\hline $0-16$ & 0 & 1 & 0 & 0 & 0 \\
\hline $16-25$ & 9 & 21 & 10 & 30 & 18 \\
\hline $26-35$ & 29 & 26 & 25 & 11 & 23 \\
\hline $36-45$ & 28 & 26 & 24 & 24 & 25 \\
\hline $46-55$ & 21 & 12 & 19 & 23 & 19 \\
\hline $56-65$ & 3 & 9 & 11 & 6 & 7 \\
\hline$>65$ & 10 & 5 & 11 & 6 & 8 \\
\hline \multicolumn{6}{|l|}{ Gender } \\
\hline Men & 67 & 49 & 57 & 39 & 53 \\
\hline Women & 33 & 51 & 43 & 61 & 47 \\
\hline \multicolumn{6}{|l|}{$\begin{array}{l}\text { Housebold employment } \\
\text { status }\end{array}$} \\
\hline Multiple earner & 65 & 55 & 51 & 61 & 58 \\
\hline Single earner & 25 & 30 & 31 & 32 & 29 \\
\hline No earner: working age & 2 & 5 & 3 & 2 & 3 \\
\hline No earner: retired & 8 & 10 & 15 & 5 & 10 \\
\hline \multicolumn{6}{|l|}{ Work history of household } \\
\hline $\begin{array}{l}\text { Continuous employment } \\
\text { of all }\end{array}$ & 60 & 48 & 62 & 48 & 55 \\
\hline Mostly all employed & 21 & 27 & 19 & 22 & 22 \\
\hline Mostly all unemployed & 16 & 15 & 7 & 19 & 14 \\
\hline Continuously unemployed & d 3 & 10 & 12 & 11 & 9 \\
\hline \multicolumn{6}{|l|}{ Gross Household income } \\
\hline$<600$ & 9 & 11 & 23 & 9 & 13 \\
\hline 600-1399 & 29 & 28 & 66 & 39 & 41 \\
\hline 1400-2199 & 25 & 26 & 8 & 28 & 22 \\
\hline 2200-2999 & 15 & 13 & 2 & 11 & 10 \\
\hline $3000-3800$ & 10 & 12 & 0 & 5 & 7 \\
\hline$>3800$ & 12 & 10 & 1 & 8 & 8 \\
\hline
\end{tabular}

25 tasks for others (either on a paid or unpaid basis) during the past year. They were then asked open-ended questions about the forms of undeclared work that they had conducted and its relative importance to their household income and finally, using five-point Likert scaling, attitudinal questions concerning their ability to draw upon help from others and their views of the economy, politics, everyday life and their future prospects. This article focuses on the responses to the first and fourth sets of questions, reporting first the extent, and second the nature of undeclared work. 


\section{The Extent of Undeclared Work}

To understand the degree to which the surveyed population rely on undeclared work for their standard of living, respondents were asked to name the form of work most important to them for achieving their standard of living, along with the second most important. One in six (16.4 percent) report that they primarily rely on undeclared work (see Table 2).

A further quarter who specify some other form of work as their principal source of livelihood cite undeclared work as the second most important contributor to their standard of living. Of these, some 28 percent are primarily dependent on subsistence production, 22 percent on mutual aid, 30 percent on formal employment and 14 percent on state benefits. In total, therefore, some 40 percent of all Ukraine households cite undeclared work as either the principal or second most important contributor to their standard of living.

There are, however, socio-economic variations in the extent to which different populations rely on undeclared work (see Table 3). Contrary to the 'marginality thesis' that undeclared work is concentrated amongst such populations such as the unemployed or people in deprived areas (Gallin, 2001; Kim, 2005), this survey finds that this is not the case. Just 12.5 percent of no-earner households cite undeclared work as their primary strategy compared with 23.5 percent of single-earner households and 13.9 percent of multiple-earner households. Indeed, of all households primarily reliant on undeclared work for their livelihood, some 51 percent are multipleearner households (58 percent of all households surveyed), 43 percent single-earner households (29 percent of surveyed households) and just six percent no-earner households (12 percent of surveyed households).

TABLE 2. Primary and Secondary Most Important Source of Livelihood: $\%$ of All Households

\begin{tabular}{lcccccc}
\hline & \multicolumn{5}{c}{ Secondary strategy } \\
\cline { 2 - 7 } & $\begin{array}{c}\text { Self- } \\
\text { provisioning }\end{array}$ & $\begin{array}{c}\text { Mutual } \\
\text { aid }\end{array}$ & $\begin{array}{c}\text { Un- } \\
\text { declared } \\
\text { Primary }\end{array}$ & $\begin{array}{c}\text { Employ- } \\
\text { ment }\end{array}$ & Benefits & All \\
Strategy & 0.9 & 1.7 & 2.2 & 2.4 & 0.5 & 7.7 \\
\hline $\begin{array}{l}\text { Self- } \\
\quad \text { provisioning }\end{array}$ & 0.2 & 0.9 & 1.0 & 1.4 & 1.0 & 4.5 \\
$\begin{array}{l}\text { Mutual aid } \\
\text { Undeclared }\end{array}$ & 3.4 & 4.1 & 1.5 & 6.0 & 1.4 & 16.4 \\
$\quad$ work & 10.3 & 17.5 & 18.4 & 9.5 & 5.7 & 61.4 \\
$\begin{array}{l}\text { Employment } \\
\text { Pension/ }\end{array}$ & 2.9 & 4.1 & 1.4 & 0.5 & 1.0 & 9.9 \\
$\quad$ Benefits & & & & & & \\
\hline
\end{tabular}

Source: 2005/06 Ukraine survey. 
TABLE 3. Primary Sphere Relied on by Ukraine Households, 2005/6: By Type of Household

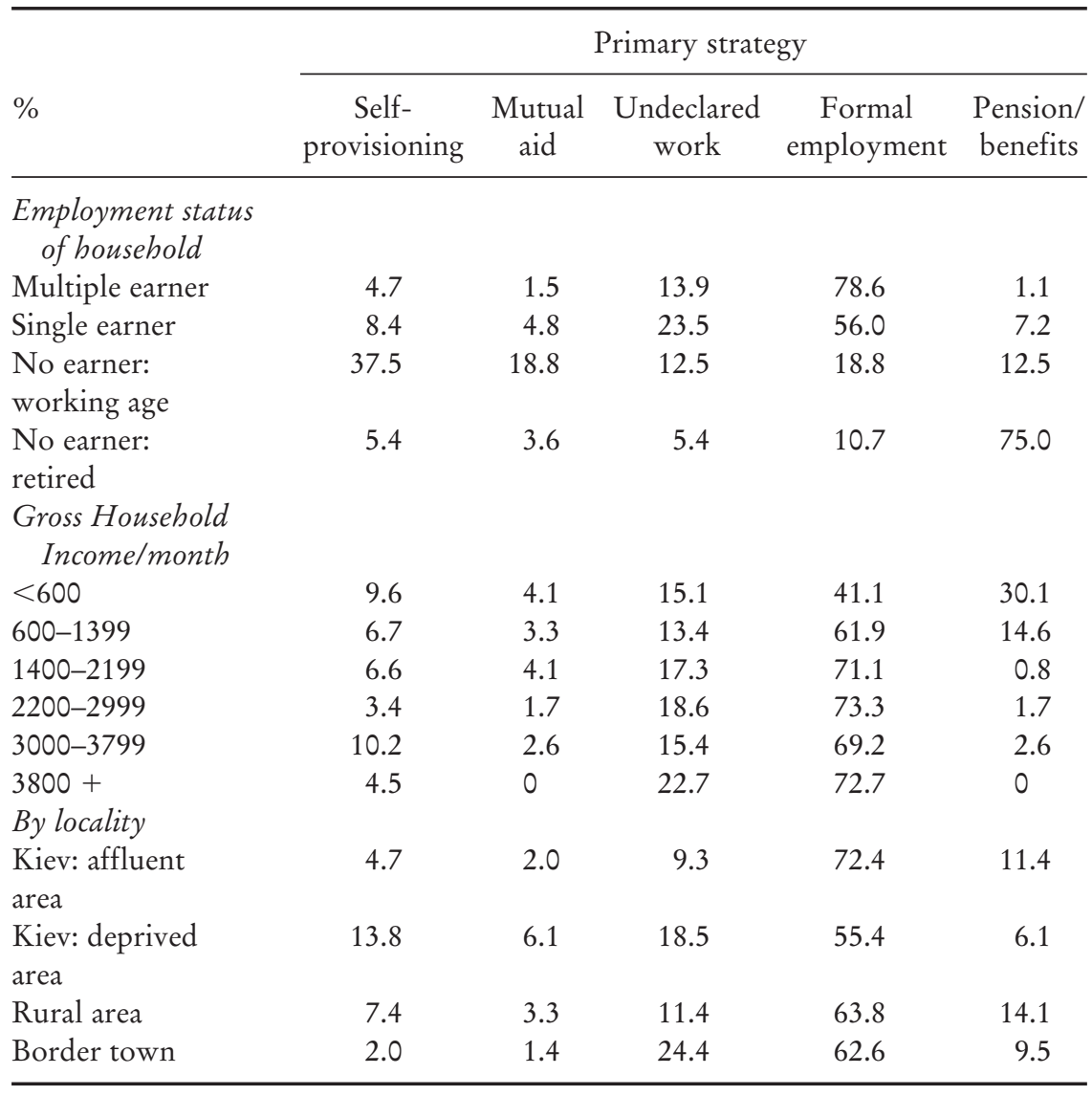

Source: 2005/6 Ukraine survey.

Similarly, it is not the poorest households who primarily rely on undeclared work; there is a fairly even distribution across the income spectrum; and if anything, such work is more concentrated in the higher-income brackets. Just 12.1 percent of households relying primarily on undeclared work have a gross household income of less than 90 (UAH600) per month (these represent 12.5 percent of all households), 35 percent earn 90-210 (41 percent of all households), 23 percent 210-330 (22 percent of all households), 13 percent earn 330-450 (10 percent of all households), seven percent 450-570 (seven percent of all households) and 11 percent more than this (seven percent of all households).

In terms of geographical disparities, deprived areas are not necessarily more dependent on undeclared work. Although just 9.3 percent of households in the affluent Kiev suburb rely primarily on undeclared 
work compared with 18.5 percent in the deprived Kiev neighbourhood, only 11.4 percent in the deprived rural area do so and 24.4 percent in the relatively affluent border town of Užhgorod. There is thus no simple correlation between deprivation and undeclared work. This study thus reinforces the wealth of previous literature that has refuted the marginality thesis both in western nations (Renooy, 1990; Williams, 2005) and transition economies (Rosser et al., 2000; Wallace and Latcheva, 2006).

Turning to the gendered nature of undeclared work, just 37 percent of undeclared work is conducted by women, whose undeclared wage is on average 33 percent less than men's; thus undeclared work reinforces the gender inequalities in the formal labour market. In part, however, this can be explained by the fact that women are more likely to engage in undeclared work for friends, neighbours and kin, which although lower paid is not conducted purely for the purpose of financial gain. The types of task conducted are also heavily gendered, again mirroring both the formal economy and the gender division of domestic labour, with women engaged especially in personal and caring services such as child-care and domestic service, and men undertaking construction and manufacturing-oriented activities. The nature of undeclared work is further investigated below.

\section{Forms of Undeclared Work}

The widespread recognition that undeclared work is not always conducted by marginalized groups has challenged the conventional negative depiction of such work as low-paid, exploitative and positioned at the bottom of a hierarchy of types of employment. What has emerged is a segmented undeclared labour market with a hierarchy of its own (Clarke, 2002; Neef, 2002; Williams and Windebank, 1998). Until now, this segmented labour market has usually been depicted as composed of undeclared employees working for businesses earning low wages and working under exploitative conditions and those working on a self-employed basis earning higher wages and with greater autonomy over their work (Castells and Portes, 1989; Williams and Windebank, 1998). This Ukraine survey, however, indicates the need for a richer and more textured understanding of the diverse work relations involved in each of these two types of undeclared work.

\section{Undeclared Employees}

Some 28 percent of all undeclared work identified in this survey involves people working 'off-the-books' for a business, while some 25 percent of all respondents asserted that they had engaged in such work over the past year. Until now, one particular type of undeclared employee has been 
heavily emphasized in the literature on undeclared work, namely those marginalized populations excluded from the formal labour market and working under degrading, 'sweatshop-like' conditions, especially in the garment manufacturing sector (Bender, 2004; Espenshade, 2004). Although such employees cannot be ignored and instances were identified of people being employed in wholly off-the-books sweatshops, these represent only a minor segment of all undeclared employees in Ukraine.

The typical undeclared employee in Ukraine is formally employed in a legitimate organization, but receives part of the wage cash-in-hand, as Neef (2002) also identifies in Romania and Sedlenieks (2003) in Latvia. This is a practice that applies not just to lower-paid workers but across the income spectrum. Indeed, some 30 percent of formal employees interviewed were paid by their employer in such a manner. Although sometimes this cash-inhand element was for overtime, most of the time they were receiving a proportion of their core wage in this manner. Very few employees were happy with this arrangement. This was not because they had experienced problems receiving this element of their wage - none said that this was the case - but because receiving part of their wages in this manner affected their social security and pension entitlements as well as their ability to apply for visas to travel abroad and obtain credit, since their official wage was lower than their actual wage. Although such a practice is common in Ukraine, the formal procedures of institutions such as banks do not take it into formally account when making decisions on loans (even if informally they do so). As one respondent seeking a mortgage recounted, the bank informed him that he would need seven guarantors because of his 'low' wages. Getting seven people together was not a problem but as he stated:

all my work colleagues had pieces of paper with them that said they earn only 300 per month, which was not enough for the bank. However, all seven had SUV vehicles parked outside the building. We had to take the bank manager outside to show them to him and say 'this is what we really earn'. In the end they agreed to give me the loan.

Besides those formal employees receiving a portion of their wage off-thebooks, another group of undeclared employees are those working for businesses in which they do not hold a formal job. This takes many forms, as Clarke (2002) has shown in Russia. On the one hand, there are those working for wholly off-the-books businesses and on the other, and more prevalent, those working for legitimate businesses that pay a portion of their workforce on an undeclared basis. Such work was sometimes full-time but more often part-time, temporary or occasional. Some 70 percent hold a formal job and engage in such work on a temporary, part-time or occasional basis to supplement their formal wages. Many worked for construction companies, restaurants and manufacturing businesses, especially in the clothing industry. 
The remaining 30 percent working off-the-books for businesses in which they do not hold a formal job are economically inactive or unemployed. Often they are early retired. Examples of the work they undertake are multifarious but include labouring in the construction industry, taxi-driving, serving on market stalls, restaurant work and staffing assembly lines in manufacturing. These tend to be the lowest-paid of all undeclared workers. One early retired man, for example, regularly worked 24-hour shifts as a security guard in the block of flats in which he lived, on a cash-in-hand basis to top up his state pension. The formally employed security guard who unofficially subcontracted this work paid him one-tenth of his salary.

The lesson from Ukraine, therefore, is that undeclared employees are distributed across the income spectrum and engage work practices as varied as those found in the formal labour market. The policy implications are discussed below.

\section{Undeclared Self-employment}

Many engage in undeclared work on a self-employed basis; indeed, these undertake some three-quarters (72 percent) of all the undeclared work identified in this survey. Breaking this down in terms of the work relations involved, some 24 percent (17 percent of all undeclared work) is conducted by the self-employed on a for-profit basis for clients previously unknown to, or only vaguely known by, them, whilst the remaining 76 percent (55 percent of all undeclared work) is undertaken as a paid favour for people previously known by them, and sometimes involves a wider range of rationales than purely financial gain, such as helping others.

Given the earlier argument that a more enabling approach is emerging towards undeclared work, not least because it is now being seen as a seedbed for entrepreneurship and enterprise, it is important here to try to identify its relative importance in this regard. How many self-employed, for example, start-up their business ventures conducting some or all of their transactions on an off-the-books basis? A previous study in Russia finds that 26.5 percent of the new self-employed work on an undeclared basis as a second job at the outset, indicating how the undeclared sphere is an incubator for new self-employed businesses (Guariglia and Kim, 2006). This Ukraine survey provides further evidence of how many enterprises start-up (and continue to operate) in the undeclared sphere. Of all identified as engaged in self-employment (some 298 individuals in total), 65 percent did not have a licence to practise their trade on this basis. Some two-thirds of the self-employed therefore operate as 'ghosts' unregistered by the state, indicating that the tendency to start-up and continue working wholly offthe-books is widespread. These ghosts, however, represent but one segment of the self-employed working on an undeclared basis. 
Of those with a licence and therefore registered as self-employed, some 85 percent reported conducting a portion of their trade on an undeclared basis. Some 90 percent of all registered self-employed interviewed, moreover, asserted that they had started-up their enterprises on a cashin-hand basis and that it was only once they became more established that some of their trade had shifted into the legitimate sphere. This has major policy implications. Given the current emphasis on new business start-ups as a route to economic development, it strongly suggests that deterring undeclared work will mean governments stamping out with one hand precisely the entrepreneurship and enterprise that with another hand they are so desperately seeking to nurture. This is not an issue for only a small proportion of business start-ups; nine in 10 entrepreneurs who had started-up a self-employed enterprise had done so on an undeclared basis and some two-thirds of these had still not even registered their enterprises, let alone declared any of their income to the state.

Despite this widespread tendency to operate wholly or partially offthe-books, most would like to legitimize their operations. Reflecting the opinion of the vast majority is a woman in her 40s who has established a successful catering business:

I would like to have my own 'legit' business. I would be very proud ... People would look at me differently ... but it is very difficult ... Our chinnovniki [bureaucrats] want money, money and more money but I cannot afford to do that ... You must pay stupid tax rates and very high rates for pensions ... It simply doesn't make sense. It is a shame because it has always been my dream to be a khozyaika [enterprise owner], but it isn't to be. If I did have a 'legit' business though, I could then go to the bank and take out a loan and expand ... but because I am not formal, they won't give me any money.

The undeclared sphere is therefore not only the principal seedbed for entrepreneurship and enterprise formation in Ukraine, but a vast proportion of all business ventures remain wholly within its interstices. If this large hidden enterprise culture were to be harnessed, it seems that this would allow these entrepreneurs to develop and grow their businesses, something that at present they find very difficult.

This survey reveals, however, that an enabling approach that simply attempts to transfer off-the-books work conducted on an autonomous basis into the formal economy is insufficient. This is because not all such work is conducted under a relationship akin to formal employment. A large proportion is conducted for neighbours, friends and kin under work relations more like mutual aid. Although some 'paid favours' for family, friends and neighbours are conducted solely for financial gain, the vast majority are undertaken both to make money and to help out others. For suppliers, paid favours are conducted to make a little money 'on the side' but at the same time to provide some service to people they know 
who would otherwise be unable to get the job done. For consumers, meanwhile, people they know are often paid for performing some task in order to redistribute money to them in a way that does not appear to be 'charity' and also to develop or cement social ties. Some 80 percent of customers, if they had not employed the person to conduct this work, would either have not had it done or would have performed it themselves. It therefore seems highly unlikely that much of this undeclared work could be turned into formal employment.

Some 55 percent of all undeclared work identified in this survey was of this variety. Indeed, 18 percent of all undeclared work was for family living outside the household, 23 percent for friends and 14 percent for neighbours. These findings parallel those of a study in England, that much undeclared work is conducted for close social relations for redistributive purposes (Williams, 2004).

Of all instances where people provide favours to kin, friends and neighbours, this survey reveals that some 41 percent involved payment. To eradicate such paid favours would thus eliminate nearly half of all acts of one-to-one reciprocity in Ukraine. Some 36 percent of exchanges with relatives are paid, 56 percent of exchanges between neighbours and 46 percent of those between friends. Although some might suggest that a laissez-faire approach of benign neglect could be adopted towards such endeavour, this study suggests the need for caution. Not only would it be difficult to distinguish between these paid favours that constitute over half of all undeclared work in Ukraine, and profit-motivated undeclared work, but also there are some significant socio-economic disparities. Higher-income households give and receive some 41 percent more paid favours than the average household, whilst the lowest-income households receive and provide just one half of the paid favours of the average household. The implications are important.

\section{Conclusions and Policy Implications}

Throughout Europe in general, the industrial relations problem of tackling undeclared work has moved to the top of the public policy agenda. In Ukraine, solving this problem has been named as the top public policy objective (Mission of Ukraine to European Communities, 2005; NRCU, 2005). The aim of this article has been to advance knowledge on the nature of such work so that it can be tackled.

Although the specific national political-economic and social context of Ukraine means that this country has a larger undeclared sector than those in the EU-15, or indeed the CEE-8 (Schneider and Enste, 2000), and also that some types of undeclared work will be relatively more prevalent (such as formal employees receiving a proportion of their wages cash-in-hand 
because of a widespread perception of state corruption that results in low tax compliance), there is no reason to suppose that the multiple forms of undeclared work identified here in Ukraine do not exist in other European nations. Indeed, although not so far mapped in such detail elsewhere, this diversity is becoming increasingly apparent whenever the nature of undeclared work is unpacked in other European nations (Clarke, 2002; Renooy et al., 2004; Williams, 2004, 2006). What are the public policy implications of this diverse nature of undeclared work?

Until now, a negative and narrow depiction of such work has informed the dominant public policy approach in many nations, encouraging efforts to deter participation by increasing punishments and detection rates so as to change the cost-benefit calculation of participants. In recent years, however, the recognition that the undeclared sphere may inspire entrepreneurship and enterprise has led to calls for an approach to harness rather than deter this hidden enterprise culture. This survey, although based on a relatively small sample, has provided strong support for such an approach, showing that some two-thirds of people setting up business ventures operate wholly off-the-books, not even registering as self-employed, and that the vast majority interviewed who had set up a business had started it up by conducting at least a portion of their transactions on an undeclared basis. Although such proportions are likely to be lower elsewhere in Europe because of higher levels of tax morality, this finding nonetheless reinforces the view that there is a need to shift from deterring undeclared work to facilitating its formalization both in Ukraine in particular and Europe more generally.

Nevertheless, too often such an enabling approach has taken the form of a 'low road' policy to deregulate the formal economy through regulatory simplification and tax reductions (European Commission, 2003a; Mission of Ukraine to European Communities, 2005; NCRU, 2005; Novoseletsky, 2000). Adopting an enabling approach towards enterprise and entrepreneurship in the undeclared sphere does not have to take this form. A 'high road' approach could be adopted, seeking to bring the hidden enterprise culture into the formal economy by combining push initiatives ('sticks') in the form of deterrents and more effective detection with pull initiatives ('carrots') to encourage these self-employed workers to legitimize their operations. These range from supply-side incentives (encouraging suppliers to formalize their undeclared work) including society-wide amnesties, individual-level amnesties and advisory and support services to help micro-enterprises formalize; demand-side initiatives to encourage customers to use formal rather than undeclared labour, such as voucher schemes; and initiatives to improve tax morality and elicit participation in the declared economy by replacing direct (compliance) with indirect (commitment) control methods, in order to develop a 'high commitment society' (Williams, 2006). 
Such a high road approach could also be applied to tackling undeclared employees, a form of undeclared work that until now - because of its 'sweatshop' depiction - has been subjected solely to a deterrence approach. If undeclared employees are to be tackled, however, then one starting point is to deal with the widespread perception of corruption amongst public officials. By increasing transparency in public life and moving from indirect to direct control methods, coupled with amnesties, support and advice, this widespread problem in Ukraine of employees working on an undeclared basis might start to be resolved as tax morality improves. Although the issue of state corruption is less prevalent elsewhere in Europe, it is perhaps still the case that increasing transparency about public spending and moving from indirect to direct control methods, coupled with amnesties and business support, remain necessary initiatives if tax morality is to be improved.

Even if there were a switch to such a high-road approach, this would still be insufficient for dealing with undeclared work. Since over half of all undeclared work comprises paid favours more akin to mutual aid than employment, and this is a principal means of providing one-to-one aid, this cannot be transferred into the formal economy. What, therefore, is to be done about this segment of the undeclared sphere? One option is to turn a 'blind eye' to such endeavour by adopting a laissez-faire approach. Although this might seem superficially appropriate, there are major problems with this option. First, public officials throughout Europe involved in tax collection will find it difficult to distinguish between undeclared work conducted primarily for economic gain (which they are seeking to encourage to 'go formal' using a combination of deterrents and incentives) and paid favours (which they would be asked tacitly to condone). A second important issue regarding the tacit condoning of paid favours relates to the resultant continuation of the uneven distribution of such work. At present, that is, higher-income households receive and undertake such work far more than lower-income households, as shown above.

Another option, therefore, is to seek to facilitate its legitimization but into the realm of legitimate mutual aid (rather than formal employment), using policy initiatives that also facilitate the inclusion of those currently unable to draw upon such social support networks. This could be achieved by developing mutual-exchange systems that reflect the seemingly emergent cultural tendency for payment to be made when people conduct favours for each other, such as local exchange and trading schemes (LETS), and exempting 'favours' in these systems from being counted as income for tax and social security purposes. Indeed, one recent evaluation found that some 35 percent of exchanges on LETS would have been previously undertaken on an undeclared basis if the LETS did not exist (Williams et al., 2001). 
The net result would be a move beyond a deterrence approach and towards one which combines deterrents with a 'high road' enabling approach that recognizes the multifarious nature of undeclared work and provides push and pull initiatives both to help the hidden enterprise culture and undeclared employees to move into the formal economy and to transfer paid favours into a realm of legitimate mutual aid. Whether or not this more enabling approach is deemed the appropriate way forward, it is now certain that a deterrence approach cannot succeed. Governments, if they persist with such an approach, will with each new initiative to deter undeclared work destroy not only the self-employment and entrepreneurial endeavour but also the active citizenship that they are seeking through other policies to nurture. The richer and more textured understanding of the diverse forms of undeclared work developed in this article demonstrates the importance of developing more complex policy solutions for the different forms of undeclared work, as well as the need to join-up policy in the realms of undeclared work, entrepreneurship and active citizenship.

\section{ACKNOWLEDGEMENTS}

The empirical data reported in this article arise from a project entitled 'Surviving Post-Socialism: Evaluating the Role of the Informal Sector in Ukraine', funded by the UK Economic and Social Research Council (RES000220985). I am indebted to Peter Rodgers for research assistance and to John Round for helping me to understand the background issues in transition economies, as well as to Richard Hyman and the anonymous reviewers of an earlier version of this article for their insightful and constructive comments.

\section{REFERENCES}

Bender, D.E. (2004) Sweated Work, Weak Bodies: Anti-sweatshop Campaigns and Languages of Labor. New Brunswick, NJ: Rutgers University Press.

Castells, M. and Portes, A. (1989) 'World Underneath: The Origins, Dynamics and Effects of the Informal Economy', in A. Portes, M. Castells and L.A. Benton (eds) The Informal Economy: Studies in Advanced and Less Developing Countries, pp. 11-37. Baltimore, MD: Johns Hopkins University Press.

Chernyshev, I. (2006) 'Socio-economic Activity and Decent Work in Ukraine: A Comparative View and Statistical Findings', Working Paper no 76, ILO, Geneva.

Clarke, S. (2002) Making Ends Meet in Contemporary Russia: Secondary Employment, Subsidiary Agriculture and Social Networks. Cheltenham: Edward Elgar.

De Soto, H. (1989) The Other Path: The Economic Answer to Terrorism. London: Harper and Row.

Dzvinka, R. (2002) 'How Does the Unofficial Economy Interact with the Official One?’, Economics Education and Research Consortium, MA thesis, National University of Kyiv-Mohyla Academy, Kiev. 
Espenshade, J. (2004) Monitoring Sweatshops: Workers, Consumers and the Global Apparel Industry. Philadelphia, PA: Temple University Press.

European Commission (1998) 'Communication of the Commission on Undeclared Work', available online at: [http://europa.eu.int/comm/ employment_social/empl_esf/docs/com98-219_en.pdf].

European Commission (2002) 'Commission Calls on Governments to Do More to Fight the Shadow Economy’, press release IP/02/339, Brussels, European Commission.

European Commission (2003a) 'European Commission Proposes 10 Priorities for Employment Reform’, press release 0311, Brussels, European Commission.

European Commission (2003b) 'Council Resolution on Transforming Undeclared Work into Regular Employment', Official Journal of the European Union, 29 October, C260, available online at: [http://europa.eu.int/eur-lex/en/archive/index.html].

European Commission (2005) Feasibility Study of a Direct Survey of Undeclared Work in Europe. Brussels: European Commission.

Gallin, D. (2001) 'Propositions on Trade Unions and Informal Employment in Time of Globalization’, Antipode 19(4): 531-49.

Grabiner, Lord (2000) The Informal Economy. London: HM Treasury.

Guariglia, A. and Kim, B.Y. (2006) 'The Dynamics of Moonlighting in Russia', Economics of Transition 14(1): 1-45.

Hasseldine, J. and Zhuhong, L. (1999) 'More Tax Evasion Research Required in New Millennium', Crime, Law and Social Change 31(1): 91-104.

International Labour Office (ILO) (2002) Decent Work and the Informal Economy. Geneva: International Labour Office.

Kim, B.Y. (2005) 'Poverty and Informal Economy Participation: Evidence from Romania', Economics of Transition 13(1): 163-85.

Leonard, M. (1994) Informal Economic Activity in Belfast. Aldershot: Avebury.

Mission of Ukraine to European Communities (2005) 'President States 2006 Budget's Main Objective as Economy's De-shadowization and Social Reforms', 1 November, available online at: [www.ukraine-eu.mfa.gov.ua/eu/ en/publication/content/4729.htm], accessed 9 April 2006.

National Radio Company of Ukraine (NRCU) (2005) 'President States Solving Problem of Ukrainian Economy's Shadowization as Incumbent Authority's Prime Objective', available online at: [http://nrcu.gov.ua/ index.php?id=148\& listid-10721], accessed 9 April 2006.

Neef, R. (2002) 'Aspects of the Informal Economy in a Transforming Country: The Case of Romania', International Journal of Urban and Regional Research 26(2): 299-322.

Novoseletsky, E. (2000) 'The Program to Bring Activities Out of the shadow Economy is on the Agenda', in J.M. Szyrmer and D. Snelbecker (eds) Reforms for Ukraine: Ideas and Actions, pp. 32-59. Kiev: Centre for Social and Economic Research.

OECD (2002) Measuring the Non-Observed Economy. Paris: OECD.

Renooy, P. (1990) The Informal Economy: Meaning, Measurement and Social Significance. Amsterdam: Netherlands Geographical Studies no. 115. 
Renooy, P., Ivarsson, S., van der Wusten-Gritsai, O. and Meijer, R. (2004) Undeclared Work in an Enlarged Union: An Analysis of Shadow Work - An In-depth Study of Specific Items. Brussels: European Commission.

Rose, R. (2005) Insiders and Outsiders: New Europe Barometer 2004. Glasgow: Studies in Public Policy 404, Centre for the Study of Public Policy, University of Strathclyde.

Rosser, J.B., Rosser, M.V. and Ahmed, E. (2000) 'Income Inequality and the Informal Economy in Transition Economies', Journal of Comparative Economics 28(1): 156-71.

Sandford, C. (1999) 'Policies Dealing with Tax Evasion', in E. Feige and K. Ott (eds) Underground Economies in Transition: Unrecorded Activity, Tax Evasion, Corruption and Organized Crime, pp. 87-100. Aldershot: Ashgate.

Sauvy, A. (1984) Le Travail Noir et l'Economie de Demain. Paris: Calmann-Levy. Schneider, F. and Enste, D.H. (2000) 'Shadow Economies: Size, Causes and Consequences', Journal of Economic Literature 38(1): 77-114.

Sedlenieks, K. (2003) 'Cash in an Envelope: Corruption and Tax Avoidance as an Economic Strategy in Contemporary Riga', in K.-O. Arnstberg and

T. Boren (eds) Everyday Economy in Russia, Poland and Latvia, pp. 37-52. Stockholm: Almqvist \& Wiksell.

Small Business Council (2004) Small Business in the Informal Economy: Making the Transition to the Formal Economy. London: Small Business Council.

SBS (2005) Government Response to the SBC Report on the Informal Economy. London: Small Business Council.

Thomas, J.J. (1992) Informal Economic Activity. Hemel Hempstead: Harvester Wheatsheaf.

Wallace, C. and Latcheva, R. (2006) 'Economic Transformation Outside the Law: Corruption, Trust in Public Institutions and the Informal Economy in Transition Countries of Central and Eastern Europe', Europe-Asia Studies 58(1): 81-102.

Williams, C.C. (2004) Cash-in-Hand Work: The Underground Sector and the Hidden Economy of Favours. Basingstoke: Palgrave Macmillan.

Williams, C.C. (2005) 'The Undeclared Sector, Self-employment and Public Policy', International Journal of Entrepreneurial Behaviour and Research 11(4): 244-57.

Williams, C.C. (2006) The Hidden Enterprise Culture: Entrepreneurship in the Underground Economy. Cheltenham: Edward Elgar.

Williams, C.C., Aldridge, T., Lee, R., Leyshon, A., Thrift, N. and Tooke, J. (2001) Bridges into Work? An Evaluation of Local Exchange and Trading Schemes (LETS). Bristol: The Policy Press.

Williams, C.C. and Windebank, J. (1998) Informal Employment in the Advanced Economies: Implications for Work and Welfare. London: Routledge.

COLIN C. WILLIAMS is Professor in the University of Sheffield, School of Management.

ADDRESS: School of Management, University of Sheffield, Sheffield S1 9DT, UK. [e-mail: c.c.williams@sheffield.ac.uk] 